Research Article

\title{
Female Sex Offenders and Pariah Femininities: Rewriting the Sexual Scripts
}

\author{
Sharon Hayes and Bethney Baker \\ School of Justice, Queensland University of Technology, Brisbane, Qld 4000, Australia \\ Correspondence should be addressed to Sharon Hayes; s.hayes@qut.edu.au
}

Received 2 July 2014; Revised 22 October 2014; Accepted 24 October 2014; Published 25 December 2014

Academic Editor: Xiaojin Chen

Copyright (C) 2014 S. Hayes and B. Baker. This is an open access article distributed under the Creative Commons Attribution License, which permits unrestricted use, distribution, and reproduction in any medium, provided the original work is properly cited.

\begin{abstract}
This paper aims to analyze the way in which the media reports of sex offences tend to reinforce traditional sexual scripts and gender identities. Compared to investigations into male sex offenders, female sex offending is relatively underresearched, undertheorized, and misunderstood (Hayes and Carpenter, 2013). We argue that the media's reinforcement of traditional scripts has hindered the development of awareness of sex offending by women, depicting them as aberrations, that is, as "female pariahs." As Harris (2010) notes, female sex crimes cannot be explained by male theories of crime. To address this issue, we examined 487 media reports from Australia and the United Kingdom and found that, as key stakeholders in public debate, the media does indeed play a crucial role in shaping the public perceptions of female sex offenders as aberrations and pariahs. This distorted view influences approaches to understanding and acknowledging sex offending by women as well as hindering the safe and timely reporting of offences by victims.
\end{abstract}

\section{Introduction}

This paper explores how media reports sex offenders, in particular, female sex offenders. Research to date indicates that it is difficult to determine prevalence of child sexual abuse due to high levels of underreporting [1,2], and this necessarily impacts on what we know about the gender of sex offenders. Nevertheless, "official statistics" do exist and generally indicate the majority of sex offenders are male and most victims are female [3]. As a result, most sex offending research has tended to focus on male perpetrators and female victims [4-7]. Recent research, however, shows an increase in numbers of both convicted female sex offenders and male victims under 16. Boroughs [8], for example, reports that in the United States in the late 1990s official statistics show that women made up $25 \%$ of convicted abusers of children under 16. In the United Kingdom, The Lucy Faithful Foundation reported in 2009 that up to $30 \%$ of sexual abusers of children under 16 are women (cited in [9]). Gleb 2007 [10, p. 16] reports that, of the 853 sex offenders adjudicated in Magistrates Courts across Australia in 2004-5, only 12 were women, although these statistics were not broken down according to age of victim, and there are no statistics to date reporting the numbers of female pedophiles in Australia. Again in the Australian arena, MAKO, a website devoted to identifying sex offenders in Australia, reports that out of "over 1500 " identified offenders, only 29 are female. However the methodology for arriving at these figures is unclear. Nathan and Ward [11] report that the official rate for Australia is $5 \%$ of all sexual offences against children but that the true number is thought to be considerably higher. The fact that Australian statistics tend to be far lower than those reported in the United States and United Kingdom suggests that there are some anomalies in the way official statistics are kept in this country or that female sexual abuse is highly underreported, or both.

Current research suggests that the typical female sex offender is aged early-twenties to midthirties, is poorly educated, and has higher levels of underemployment and lower socioeconomic status [12]. The psychological literature indicates that female sex offenders have a higher-than-average tendency toward mental health problems, including personality disorders, substance abuse, depression, and "poor coping skills," as well as severe victimization experiences $[12,13]$. Nathan and Ward [11] claim that most female offenders are passive, usually committing offences as accomplices to men; 
however, the methodology for arriving at that conclusion seems unclear.

While there has been an increase in recent years in research and debate over what motivates female sex offenders, much emphasis has been placed on developing "typologies" $[14$, p. 33] in order to identify, apprehend, and treat such offenders. Mathews et al. [15] in [7, p. 291], for example, propose five typologies based on 16 women in a community correctional centre: teacher-lover; predisposed molester (victim of sexual abuse); male coerced molester; experimenter/exploiter; and psychologically disturbed. However, Sradjian and Hanks [16] note that there is also the "atypical female sex offender" and that women typically do not fit neatly into these categories at all.

Current scholarship (e.g., $[1,2,6,17,18]$ ) indicates that there is significant underreporting of child sexual abuse (i.e., sexual crimes perpetrated on children under 16 years of age) and, in particular, abuse perpetrated by females. Denov [6], for example, notes there is a "culture of denial" surrounding female sex offenders. Similarly, Eastwood [18] claims that female sex offending is the "silent crime."

Factors impacting on the underreporting of sexual offences include embarrassment, self-blame, fear of further victimization by legal processes, lack of confidence in criminal justice system, disruption to the family unit, perceptions of low impact of damage, and the fact that, for some young people (especially males), sexual precocity is seen as a rite of passage $[6,19]$. What little research there is on female sex offenders suggests that victims of sexual abuseespecially child victims - may be more reluctant to report being accosted by a female than by a male [20] or less able to recognize the behaviour as abuse [21]. Nevertheless, while the official statistics report that women commit fewer sex offences, speculation in the media and amongst those working in the field suggests that numbers of female offenders are increasing (e.g., Lucy Faithful Foundation 2009, MAKO 2011, Guardian 2009, and AAP Australian National News Wire 2006). These same statistics inform current policy and practice, which therefore remains ignorant of and blind to the impact of female sexual offences against children.

Child sex offenders are considered to be dangerous and predatory. However, it has been argued that male offenders are generally regarded as more dangerous than females [21]. This paper explores the ways in which people think about female sex offenders and whether they perceive them as being culpable in the same way as male offenders. It explores the differences in perceptions between offenders of young children and those who abuse older and pubescent children. Many of the studies conducted to date have concluded that female sexual offending is "an aberration which has little or no significance for professionals working with child sexual abuse" [22, p. 303]. The Diagnostic and Statistical Manual of Mental Disorders 4th Edition concludes that acts of paraphilia (which include pedophilia) "are almost never diagnosed in females" [22, p. 303]. According to Landor [4], given that the vast majority of research on sex offenders fails to even contemplate the female sex offender, it is reasonable to conclude that the predatory sex offender is a male.
Given that the research indicates very little difference in risk of recidivism between male and female sex offenders, it is surprising that more attention is not given to female offenders [21]. Freeman and Sandler's [23], for example, studied 780 male and female sex offenders in New York City and found that while males were more likely to be rearrested than females, actual risk factors were very similar. In terms of perceptions of dangerousness, women who offend against children under 11 are treated similarly to male offenders by both the media and the courts but do not appear to be regarded as dangerous as male offenders [17]. Women who abuse older children tend to be sentenced more lightly than their male counterparts and may or may not be required to sign a sex offender register. For example, a female teacher in Australia who was tried and convicted of abuse of a 15-yearold male student received a 22-month suspended sentence, whereas, in a similar case where the genders were reversed, the male offender received 2 years and 2 months in prison [24]. This raises several questions concerning the role of gender in both perceptions of crime and sentencing.

Most of the research on public perceptions of sex offenders is fairly old, although there has been one or two recent studies (e.g., [21]). For example, one study [25] found that $90 \%$ of parents warned their children about strangers, while very few parents suggested child sex offenders could be people known to them. Morison and Greene [26, p. 601] report that $20 \%$ of US jurors believe child sex abusers are like the stereotypical "dirty old man." They state that "identifying public perceptions of perpetrators is significant for developing public education about CSA (child sexual abuse)" [25, p. 272]. The current research seeks to address this gap by focusing on the ways in which media and general public perceive female sex offenders and the crimes they commit.

\section{Theoretical Framework}

The theoretical framework for this study is drawn from gender and sex script theory. In particular, we explore Schippers' [27, p. 95] concept of "pariah femininities" as an explanatory tool in unpacking the social construction of FSOs. Current discourses conceptualize sex offending around the notions of harm, subjectivity, and gender. In general, there appear to be two main discourses - the feminist and the psychologicalthat theorize these phenomena. In particular, the rise of feminism in the middle of the twentieth century was central to exposing the crime of child sexual abuse. Based as it was on second wave feminism at the time, it was grounded in patriarchal male domination and female victimization, which depicted male sexuality along a continuum of danger according to their potential to abuse. In some sense, all men were considered to be potential sexual predators. Feminists challenged psychological accounts that described male sex offenders as anomalies. More recent feminist scholarship has for the most part moved away from this model "to take account of the more nuanced relationships and subjectivities generated by constructions of gender and sexuality" [21]. Nevertheless, current legislation and public policy still remain focused on violence against women perpetrated by 
men. For example, the recent Australian campaign against domestic violence advocated the following: "To violence against women, Australia says no" [28].

The psychological discourse, in contrast, links sex offending closely to sexuality [24]. White and Haines [29, p. 119] argue women are treated differently because any deviation from appropriate feminine behaviour is seen as "maladjustment" and the "consequence of biological (psychological) defect." Paedophiles are considered to be essentially at high risk of reoffending, rather than acting aberrantly. Their attraction to children is regarded as typical of their distinctive sexuality and for that reason is all the more sinister because the sex offender's desire involves the exercise of power over children who may not understand or be able to resist their abuse. This is why female paedophiles are considered rare. Women's positioning as victims means that even when they offend it must be due to external pressures out of their control because they are psychologically or emotionally damaged or traumatized [17].

In addition, many current explanations of female offending tend to draw mainly upon theories of male offending [29, pp. 112-113]. While it has been argued quite extensively that men commit crime as a way of "doing gender," that is, of achieving masculinity when they have previously failed to do so legitimately, some theorists have proposed that women who commit crime embrace a "masculine identity" [30, p. 136] [19] [31, p. 498]. Such attributes as power and domination are also said to be features of the sexually aggressive woman [14, p. 32]. However, despite this attribution of masculinity, it has been found that the motives and experiences of women and men are different and therefore warrant unique explanations [14, p. 33].

According to Schippers [27, p. 94], masculinity is characterized by "desire for the feminine object, physical strength and authority," and this defines and legitimates superiority and social dominance over women. Females are primarily normalized as the gatekeepers of sexuality and subsequently are seen as nurturers and protectors in positions of trust. Female sex offenders undermine such normative labels when engaged in behaviour usually ascribed to "predators," "perverts", and "paedophiles." It is a primary contention of this paper that FSOs are not necessarily drawing on masculinity or masculine characteristics but, conversely, are failing to conform to the stereotypes associated with hegemonic femininity, which is necessarily subordinate to hegemonic masculinity [27, p. 95]. Hegemonic masculinity describes the specific characteristics of the dominant stereotype of masculinity in a given context. While always context specific, hegemonic femininity will always directly complement the specific features of hegemonic masculinity at any given time, because it is directly influenced by it [27]. This is a challenge to gender roles and the "doing" of gender. As such, female offenders challenge traditional gender roles dictated by hegemonic masculinity and femininity. Schippers terms these alternate femininities "pariah," because they are seen as socially toxic, shrouded in denial and taboo, and because they challenge the heteronormative reign of femininity and masculinity. Pariah femininities are not subordinate femininities but, rather, contaminants of the female, for example, the lesbian who desires the feminine object, the "bitch" in a position of authority, and, as we propose, the female sex offender. Such reconfigurations of the female "must be defined as deviant and stigmatized," ensuring reinforcement of the feminine "ideal" [27, p. 95].

The feminine ideal essentializes women within a normative frame as being naturally caring and sexually passive [17]. Women and girls who conform to this normative frame are positioned as "normal"; those who do not are regarded as deviant and, in the case of female sex offenders, as "doubly deviant" [32, p. 50]. A lack of femininity is attributed as causing criminal behaviour and the remedy to this is compliance to traditional gender stereotypes [33, pp. 16-17]. Further, hegemonic masculinity and femininity are employed in the maintenance of gender difference, especially with respect to the volume and type of law breaking [33, p. 176]. Denov, however, criticizes this model as a one size fits all approach, ignoring individual differences in female sex offenders. She proposes that "traditional sexual scripts" are a barrier to the recognition of sexual abuse by females [6, p. 308]. Larson and Maison (in [6, p. 308]) assert that, given our Judeo-Christian heritage, socially and as a culture we imbue women with the characteristics of warmth and nurturing. It is therefore difficult to acknowledge and subsequently detect the female sex offender [7, p. 284], [3, p. 11].

Designating females as passive, innocent, and sexually submissive has "aided in both the under-recognition and reporting of female sex offending." Such denial, coupled with the reinforcement of traditional sex scripts, also permeates institutions such as the criminal law and justice system, media, and victims themselves [6, p. 308], [31, p. 497]. Institutionalized sex scripts portray women more often as victims and men as perpetrators. Burt and Estep [34, p. 512] argue that sexual socialization plays a part here, where women "learn a sense of sexual vulnerability" whilst men are conditioned to be the sexual aggressor, based on the belief that "a man who is a victim is a failure" (see also [30, p. 130], [22, p. 1149], and [20, p. 60]). West and Zimmerman define "doing gender" as the activity of "managing situated contact in light of normative conceptions and attitudes and activities appropriate for one's sex category with such activities" [30, p. 127]. Doing gender the "right" way reinforces and legitimates the institutional arrangements based on sex category. Failing in this goal means the individual must be "called to account" [30, p. 146]. However, Linders and van Gundy-Yoder suggest a less formulaic definition stating "...gender is best approached as an evolving sexual category that gets reconstructed, modified and transformed whenever it is implicated in social practices and public debates" [35, p. 324]. Public debate is seen, routinely, in the domain of the "fourth estate," the media. Historically, media coverage provides opportunity to "...condemn gender violations" [35, p. 329].

"Weak, vacillating, sinful, but of the same sex as your mother and mine, your sister and mine" and "a beast. . and a domestic traitor" with behaviour described as "inconceivable in a woman" are comments referring, not to a female sex offender, but rather to a woman called Mary Rogers, an American woman who murdered her husband over 100 years 
ago (letters to the editor cited in media publications in 1905 in [35, p. 327]). Linders and van Gundy-Yoder note the harsh treatment given to Rogers by the media, which appeared to be confounded by her gender transgressions. As a woman and a wife she was portrayed as a "traitor" to her gender, as failing to enact her scripted role as a female; in effect, she became a "pariah." Whilst times have changed, the notion of "inconceivability" with respect to the modern day female serious offender in general and female sex offender in particular has not.

Further reference of this perception in relation to female sex offenders was made in the case of Rose and Fred West, who, in the mid-1990s, were brought to account for horrific, sexualized acts of violence and murder carried out in England over the course of a decade. Berrington and Honkatukia indicate that Rose West was effectively on trial, within not only the criminal justice system but also the media, for "lack of womanhood" and deviating from prescribed and expected "maternal and nurturing" roles [32, p. 51]. They suggest that women who do not conform to such roles are often ridiculed as a way of "neutralizing the challenges they pose to dominant and hegemonic patriarchal norms." In this respect, the media plays a pivotal role in the portrayal of events as well as how those events are "perceived, responded to and recorded for posterity" [32, p. 55]. Within this context, the tone and style of reporting may contribute to the notion of pariah femininities, since sexualized human drama and emotion provide part of the staple diet of sensationalized stories conveyed through the media [32, pp. 55-57].

\section{Methodology}

This paper aims to explore the foregoing discourses through an analysis of news articles about female sex offenders. (More general findings of this analysis were reported in Hayes [21].) Analysis was conducted via media reports collected from mainstream news media in both Australia and the United Kingdom. These two locations were chosen for the similarities in culture, convention, and social mores, but also based on the relative differences in levels of recognition of female sex offending between the two nations. Female sex offenders are more apparent in media and other public discourses in the UK compared to Australia, suggesting that Australians are yet to "catch up" to the UK in recognizing female sex offenders as an issue. Disparities in statistics described above in the background literature also suggest that victims of female sex offenders may be more reluctant to report in Australia due to that lack of recognition. The current media analysis is not intended to test either of those preliminary hypothesesindeed, a much larger and more directed survey of public opinion is required for such research. Rather, the current project seeks to explore public discourses surrounding female sex offenders to identify possible themes, as well as any similarities and/or differences between the two locations.

News articles were collected from online print media, including The Guardian, The Times, The Observer, The Daily Mail, syndicated press reports (e.g., from Associated Newspapers, The Press Association, and News Ltd.), and independent press reports in smaller news media sites in the UK. In Australia, reports were collected from The Age, The Sydney Morning Herald, The Australian, The Courier Mail, Northern Territory News, and syndicated press reports from AAP Australian Associated News Wire reported on smaller news sites and accessed through the Australia/New Zealand Reference Centre database. The timeframe for the data collection was 2000 through $2010(n=485)$.

Of the 485 news articles collected, 76 were discarded as being unrelated to the current research, specifically where a woman was mentioned in relation to a sex offence but was not charged or arrested for any offence. In addition, 17 articles were general reports about female sex offenders including reports of research being published on the issue or comments by public figures of a general nature. Of the remaining reports, 290 were reports of prepubescent abuse (aged 11 and under) and 102 were reports of abuse against pubescent and adolescent children (aged 12-16).

Initial coding divided the reports into two groups: those concerned with prepubescent victims (aged 11 years and under) and those concerning pubescent and adolescent children (aged 12-16). Coding was done manually by reading through the reports and identifying common and/or popularly used terms, phrases, and themes used in describing female sex offenders, their crimes, and their victims. The coding did not count these terms, phrases, or themes but was more concerned with identifying common themes and the general tone of both the comments made about female sex offenders and their crimes and the reporting of those comments and crimes. The articles were then more deeply interrogated as discourses to identify overt and covert patterns of reference to harm, subjectivity, and gender, which were key theoretical concepts informing the research. For this paper, we revisited the analysis from the perspective of pariah femininities.

This critical analysis is informed by what Graham [36] describes as the "discursive analytic", an interrogation of discourses first and most famously employed by Michel Foucault [37]. Whilst not a method in and of itself-unlike what Taylor [38] refers to as Critical Discourse Analysis-this discursive analytic informs our methodology by lighting the way for "journey and conversation" with the media reporters of female sex offenders as well as the participants in the conversations and observations reported ([36, p. 2]). Our discursive analytic is therefore not necessarily generalizable; rather it provides the impetus for identifying contradictions and anomalies that may be useful in developing some more grounded research questions for further empirical research.

\section{Findings and Discussion}

In the prepubescent group, findings revealed a total of 41 individual female sex offenders had been identified across Australia and the UK. Two of those were named Australian offenders and 24 were named offenders in the UK. Three Australian women and $11 \mathrm{UK}$ women were unnamed. In the pubescent/adolescent group, there were a total of 74 individual female sex offenders, including 6 named Australian and 
40 named British. Within this second group, 11 British women and 14 Australian women were unnamed.

The occupations of the FSOs widely varied, ranging from unemployed, child care worker, sports coach, and so forth to sexual abuse counsellor. The ages of FSOs span from 19 to 62 whilst that of victims is $10-16$ years. Relationship status was indicated in just over half of the sample. The marital status reported on the remainder is "not clear."

Our analysis of the media reports revealed that, in the case of prepubescent victims especially, most women offenders acted with or were associated with a male offender and were cast as his "accomplice." Intimations of vulnerability and manipulation by the male "ringleader" suggest that these women's behavior may be excused on some level or at the very least made coherent [21]. At the same time, however, they are also painted as "horrific" and "evil" and their deeds as the "ultimate female betrayal," and the discourses offered by the public when asked for comment were of the nature of "a mother wouldn't do that" [21]. These offenders were disparaged and maligned even more so than their male cooffenders.

Overall, thirty of the articles were directly representative of the "pariah" construct of FSOs, offering language explicit to the theme. Six subthemes were identified: (1) demonization; (2) sensationalism and titillation; (3) minimization and mitigation; (4) medicalization and psychologizing; (5) romanticizing FSOs; and (6) women as nurturers. Each of these is discussed below. (3), (5), and (6) speak directly to pariah femininities. While the first clearly treats FSOs as pariahs, in the following five themes, we see how the media portrays FSOs in a manner that attempts to draw them back into gender hegemony, finding them damaged and vulnerable, which provides some explanation or even excuse for their pariah status.

4.1. Demonization. The last theme to emerge from the analysis was the demonization of FSOs, what we describe as the creation of a "toxic pariah." No fewer than thirteen of the named offenders and seven of the unnamed offenders were framed as toxic pariahs. The list of descriptors for their crimes varied. Collectively, the terms "indecently assaulted," "gross indecency," "sexual abuse," "indecent assault," "sexual assault," "lewd and libidinous behavior," "ordered to sign sex offenders register," "female paedophile," "sex charges involving underage girl," "serious sexual assault," "indecency with a child," "committing an act of gross indecency," "sexual abuse of children," and "indecent act" all contribute to the highlighting of behaviour "toxic" to the traditional gender roles. Trueman, Vercoe, and Bromiley are particularly prominent examples, their offending described in terms of being "toxic" to hegemonic femininity. The crimes committed by Bromiley, the "pervert woman carer," were attributed by the Judge with being the "worst case of a woman abusing children" he had ever encountered. This tone of describing and reporting also extended to Vercoe. Descriptions of her offending as "predatory" and as "initiating sexual contact" with the victims she had "lured" likewise portrayed her as a pariah. However, perhaps the most toxic of descriptions are those referring to the Trueman case. In reports describing the intimate details of her actions towards her victim and her "posing" as a male, she is characterized as portraying the ultimate betrayal of "femininity, a lesbian. Other descriptors and phrases which are suggestive of pariah femininities include "abusing," "sex attacks," "revulsion," "predatory," "preyed on both youngsters," "revulsion felt by the community," "shameful," "shocking," "cynical," "public horror," "terrifying," "female abuse," "female/bisexual paedophile," "utterly shameful," "allegations are terrible," "cruelty," "preyed," "catalogue of abuse," "children mentally and educationally disadvantaged," "lookout while husband raped girl," and "encouraging girl to undress." Such emotionally charged descriptions incite shock and sensationalism but may also be said to contribute to the renunciation of women who do not fulfil the idealized and stereotypical vision of hegemonic femininity or adequately conform to heteronormative female sex scripts.

4.2. Sensationalism and Titillation. Berrington and Honkatukia [32, p. 50] propose that press accounts of sex offences are often underpinned by sexuality and gender relations. At the same time, what is considered "unusual" and "atypical" shocks the audience with their "rarity" [32, p. 59]. The demand for and supply of explicit material are implied by reports that are "intrusive," "personalised," and "voyeuristically satisfying." One of the dominant themes emerging from the present analysis was that of sensationalism and titillation. Many of the article titles in the sample used gender stereotyping to emphasize the fact that a "woman," "wife," "lesbian pervert," or "female groomer" was implicated as a female sex offender. The words "mother," "wife," "woman," and "abuse" were often in bold. Clearly, these reports were comparing the FSOs pariah status with their status as women, mothers, and wives.

Fifteen of the articles (of both named and unnamed offenders) conveyed details and imagery that may be described as sensational and titillating to the audience. The case of Bromiley conveyed "virgin victims," whilst Morales was described as having "soft, full and sensual lips that hunt me in my dreams" by her alleged fifteen-year-old male victim. Trueman, however, was probably reported to be the most dangerous pariah. When twenty-three-year-old Trueman posed as a boy in order to befriend and later seduce a twelve-year-old girl, the news report described her as a "lesbian pervert" who put her "hand down the girl's trousers" and "pestered her to let her perform a sexual act on her." Apparently her status as a pariah did not damage the titillation factor regarding her actions. Similarly, Hallam's victim was reported as saying, "Just to have an older woman do that was one of my fantasies." Likewise, the acts of lone offenders, Grice, Beck, Ginnetta, Sullivan, Lane, Wilson, Vercoe, and Poole (as well as three unnamed offenders), were painted in detail to stimulate the reader's imagination.

It is of interest to note that, as opposed to lone offenders, the reports covering women who were "accomplices" more frequently (five instances) refrained from naming the offender/s in order to "protect" the victims. In cases where accomplices were named, the readers were provided with 
more details and mental images in order to keep them engaged. The article on Jones described her as a woman who was forced, along with her two fifteen- and sixteen-yearold male victims, to pose for photographs with "sex toys" purchased by her husband. Those readings about Lundon, who was given a four-year custodial sentence, were treated to descriptions of sexual activity both in front of and with a twelve-year-old female victim and were concluded with the remark that Lundon "didn't mind sharing." Berrington and Honkatukia [32, p. 69] suggest that "as in other forms of crimes of 'deviance' women as perpetrators offer a particular fascination, with the rarity of such behaviour enhancing its newsworthiness" [32, p. 69].

4.3. Minimization and Mitigation. Women "accomplices" to male sex offenders, while constructed as pariahs, were also frequently cast as victims themselves and therefore were not fully responsible for their actions. The notion of sexual scripts helps explain how this might occur. Drawing on the stereotypical positioning of women as sexually passive and innocent [6, p. 308] compared to their stereotypically dominant and sexually aggressive counterpart supports the claim of coercion [39, p. 559]. Hayes and Carpenter [17] report that accomplice FSOs are often positioned as coerced and emotionally dependent on their male cooffender. Such positioning in the current sample was also significant. For example, Comben, a sixty-one-year old "accomplice" and former partner to cooffender, William Loftus (age 59), was jailed for eighteen months for her part in sexual offences against two girls dating back to the 1970s. Comben allegedly witnessed and was complicit in the forced performance of sex acts by the girls on her then husband. However, her counsel argued that Loftus was "dominant" in the relationship and "severely abusive" towards Comben. Whilst the trial judge, Christopher Harvey Clark, tipped his hat to pariah status by acknowledging the offences as "truly disgusting," he also proposed that Loftus was a "violent" and "domineering man," adding "[y]ou were besotted by him and you permitted him to behave in that repulsive manner without objection or intervention." As the gatekeeper of sexual propriety, Comben had failed; nevertheless she secured a degree of mitigation for her part in the offending. Mitigation or minimization discourses like these featured quite significantly in the study's findings.

4.4. Medicalization and Psychologizing of FSOs. There was considerable overlap between some themes, with some of them being mutually supportive. Thus, we found that medicalization also may be framed in terms of supporting the theme of minimization and mitigation. One good example is Lane, who was reported to be suffering from chronic fatigue syndrome and depression and was allegedly taking antidepressant medication, factors which appear to counteract her pariah status. The words and phrases used to describe one of the unnamed female sex offenders also medicalize and therefore serve to mitigate her behaviour. This latter offender also suffered from depression and was described as a "vulnerable woman with psychological problems." This offender was portrayed as not being completely responsible for her actions. Another unnamed offender was reported to be undergoing evaluation with respect to "being fit or unfit" to stand trial on the grounds of "low intelligence." This hinged on both psychological and psychiatric reports. In the same vein, Jones' sentencing was adjourned pending psychiatric and "other" reports. Reports on Lock also refer to low I.Q. and learning difficulties, with the defendant being described as "just over the borderline of being able to understand what was going on in the court." Beck was likewise medicalized/psychologized, described as "frail in body" and "terrified of prison" and subsequently mitigated with an appeal to emotion.

Another unnamed and lone FSO, whose activities of molestation were described as an "affair," was partially excused on the grounds of her "history of depression," "personal circumstances," and an abusive husband. Hayes and Carpenter [17] argue that previous victimization at the hands of men is often employed to position FSOs as victims themselves. This particular offender's "inability to respond to the opposite sex" or to have a "decent adult relationship" was blamed on her personal and psychological history. One media report suggested that "any power in the relationship" was "with the boy". This has shock value but also reinforces sexual scripts of hegemonic masculinity and femininity. The judge even asks for evidence "about harm or damage done to the boy." Not only does this reinforce traditional sex scripts, it also provides a basis for explaining why male victims of sexual assault often fail to report it [6, p. 308]. Indeed, there appears to be "strong resistance against acknowledging" this type of sexual offending [14, p. 20].

Likewise, Vercoe's offending was considered partially defensible on the grounds that she had "personal troubles," an unhappy marriage, and was effectively being "ostracised" by work colleagues. Media reports described her as having low self-esteem in the wake of committing the offences, stating that she perceived herself to be a family "failure." A second article about Vercoe highlighted how similar comments by the presiding judge and its subsequent reporting can minimize sex offenses.

4.5. Romanticizing FSOs. Appealing to romantic attachment also served to mitigate the behaviour of alleged female sex offenders. Morales, for example, wrote "loving cards and letters" to her victim, "to bolster his self-esteem," and was said to be enamoured with his "soft, sensual and full lips." Hallam would also send love letters to her victims, whilst Grice is said to have "seduced" a schoolboy with a "crush." Poole's activity, as mentioned above, was framed in terms of her "having an affair." In terms of accomplices, Lundon was described as having "sex sessions" "with her lover" and their victims. Comben, who was reportedly "besotted" with her cooffender, also received partial mitigation. These women were also denounced for their behaviour, of course, but the romance angle was, like the other mitigating explanations, used to steer her back into gender hegemony.

Romanticizing also took the less exuberant form of mutual sexual attraction, which provided some rationale for 
the inappropriate relationship. In Vercoe's case, for example, while the judge admonished her for her lack of "common sense," he went on to describe the FSO's victims as "not wholly unwilling." Sullivan also reported that she perceived her victim as a "willing participant." Finally, in the case of Beck, it was reported that the victim felt he has been exposed to "no lasting suffering." Indeed, the male victim portrayed in the article was "quite adamant" about this assertion.

4.6. Women as Nurturers. The roles of "housemother," "carer," "child-minder," "mother," "teacher," "woman," and "wife" all conjure up images of "gendered stereotypes and behavioural expectations" [17]. These roles reinforce traditional sexual scripts of the "female" as being passive, submissive, innocent, and nurturing and provide a counterpoint to what is regarded as their horrific acts. As nurturer and protector of children, such roles carry with them a position of trust. These roles are emphasized in twenty-six of the articles in the sample. For example, Grice, French, Hallam, Ginnetta, Lane, Vercoe, Poole, Ellis, and Morales along with other unnamed sex offenders are portrayed as females who, in failing as gatekeepers and nurturers, also failed their duty to or at least brought into question their claim to womanhood. Eight of these women were teachers or teaching assistants, one was a sexual assault counsellor, another was a housemother, and, finally, one woman ran an unofficial safe house. By emphasizing their roles as nurturers, the behaviour of female sex offenders becomes even more perverse.

The phrase "breach of trust" or "abuse of trust" featured heavily in the judicial comments and subsequent media coverage of the various trials. Vercoe, a twenty-five-year-old lone offender and teacher, had sex with multiple underage male students and was accused of having "broken the trust that exists between a student and teacher." Other offenders, though not teachers, were also held to account for such breaches. Trueman, the "lesbian pervert," was portrayed as the antithesis of womanhood. Her victim's mother stated, "I would hate anyone else to suffer like my daughter has." The mother of one of Bromiley's victims voiced the claim that the "pervert women carer" had stolen "...my son's childhood." Perhaps the greatest betrayal of womanhood was conveyed in the case of Sullivan, a single mother whose behaviour was described as "shameful," "shocking," and "cynical." Thirtysix-year-old Sullivan, who has a son of her own, pursued sex with her twelve-year-old male victim (her son's friend) approximately two hundred times. Not only did she offend sexually, she also kept graphic accounts in a diary. These were later viewed by the court and highlighted in media coverage. Emphasis was placed not only on her sex offences but also on her behaviour as a mother. She was portrayed as a bad mother for cutting her own son "out of her affections" while showering gifts and affection on her victim.

\section{Conclusion}

While this study has a number of limitations, we believe it makes a unique contribution to the understanding of media perceptions of sex offenders. While the size of the sample used for the analysis numbered 485 , only thirty directly emphasized the pariah nature of FSOs. Future studies based on significantly larger samples may remedy this. In addition, it would have been valuable to gather interview data from female sex offenders to ascertain whether they selfidentify themselves with the notions of pariah femininities or hegemonic femininities as portrayed in the media articles. Such research may give new insights as to the motives for such offending and therefore contribute to the body of theoretical and practical knowledge about sex offenders. Nevertheless, this study has been very useful in highlighting the extent to which the media treats female sex offenders, particularly in the ways it reinforces traditional sex scripts and employs pariah femininities.

Whilst the media is supposedly driven by its commitment to providing information about current affairs, it is also necessarily driven by financial incentives. Using the tools of sensationalism and titillation to arouse and prolong reader interest and reaction facilitates profitability. However, the media also provides rich opportunities for examining contentious issues and their related themes and discourses from a variety of perspectives. This is evident with the identification and exploration of the six subthemes within this study, particularly the ways in which pariah femininities are often offset by mitigation and minimalizing of FSO crimes. Analyzing the emergent themes of the thirty key articles within the sample reveals that, on balance, the media both reinforces gender hegemony and employs and reinforces pariah femininities, though to varying degrees.

The theme of the "toxic pariah" clearly demonstrates how women who deviate from traditional gender performance and sexual scripts reflect and can be accurately described in terms of Schippers' "pariah femininities." In addition, twenty out of the thirty articles were said to display a reporting tone that supported the notion that such femininities are a challenge to hegemonic femininity because they are undermining traditional and stereotypical sex scripts. In this respect there can be said to be a "push and pull" relationship between normative sex scripts and pariah femininities. Whilst the roles of "wife," "mother," "carer," "housemother," "sister," and "teacher" may conjure up traditional and normative female roles, the terms "lesbian pervert," "predator," and "female paedophile" suggest toxic pariah-hood. Both sets of descriptors, it is contended, create a degree of tension that helps keep the reader engaged and the contentious debate on female sex offending alive.

\section{Conflict of Interests}

The authors declare that there is no conflict of interests regarding the publication of this paper.

\section{References}

[1] Bravehearts, "Research documents: factos and stats," in Child Sexual Abuse, vol. 1, pp. 113-128, Bravehearts, 2009, http://www .bravehearts.org.au/docs/facts_and_stats.pdf. 
[2] A. Neame and M. Heenan, "What lies behind the hidden figure of sexual assault? Issues of prevalence and disclosure," Briefing no. 1, Australian Centre for the Study of Sexual Assault, 2003.

[3] H. Gavin, “"Mummy wouldn't do that" the perception and construction of the female child sex abuse," in Evil, Women and the Feminine, The Inter-Disciplinary Press, Budapest, Hungary, 2006.

[4] R. V. Landor, "Double standards? Representation of male vs. female sex offenders in the Australian media," Griffith Working Papers in Pragmatics and Intercultural Communication, vol. 2, no. 2, pp. 84-93, 2009.

[5] T. Thomas, Sex Crime: Sex Offending and Society, Willan Publishing, London, UK, 2nd edition, 2005.

[6] M. S. Denov, "The myth of innocence: sexual scripts and the recognition of child sexual abuse by female perpetrators," Journal of Sex Research, vol. 40, no. 3, pp. 303-314, 2003.

[7] D. Vandiver and J. Walker, "Female sex offenders: an overview and analysis of 40 cases," Criminal Justice Review, vol. 27, no. 2, pp. 284-300, 2002.

[8] D. Boroughs, "Female sexual abusers of children," Children and Youth Services Review, vol. 26, no. 5, pp. 481-487, 2004.

[9] M. Townsend and R. Syal, "Up to 64,000 women in UK "are child-sex offenders'”, The Observer, 2009, http://www.theguardian.com/society/2009/oct/04/uk-female-child-sex-offenders.

[10] K. Gleb, Recidivism of Sex Offenders: A Research Paper, Sentencing Advisory Council, Melbourne, Australia, 2007.

[11] P. Nathan and T. Ward, "Female sex offenders: clinical and demographical features," Journal of Sexual Aggression, vol. 8, no. 11, pp. 5-21, 2002.

[12] K. C. Faller, "The spectrum of sexual abuse in daycare: an exploratory study," Journal of Family Violence, vol. 3, no. 4, pp. 283-298, 1988.

[13] A. D. Grayston and R. V. de Luca, "Female perpetrators of child sexual abuse: a review of the clinical and empirical literature," Aggression and Violent Behavior, vol. 4, no. 1, pp. 93-106, 1999.

[14] D. Harris, "Theories of female sexual offending," in Female Sexual Offenders: Theory, Assessment and Treatment, T. Gannon and F. Cortoni, Eds., pp. 31-51, John Wiley and Sons, West Sussex, UK, 2010.

[15] R. Mathews, J. Matthews, and K. Speltz, Female Sexual Offenders: An Exploratory Study, Safer Society Press, Orwell, Vt, USA, 1989.

[16] J. Sradjian and H. G. I. Hanks, Women Who Sexually Abuse Children: from Research to Clinical Practice, John Wiley \& Sons, 2006.

[17] S. Hayes and B. Carpenter, "Social moralities and discursive constructions of female sex offenders," Sexualities, vol. 16, no. 1-2, pp. 159-179, 2013.

[18] C. Eastwood, "The experiences of child complainants of sexual abuse in the criminal justice system," Trends and Issues in Crime and Criminal Justice, no. 250, pp. 1-6, 2003.

[19] R. Deering and D. Mellor, "An exploratory qualitative study of the self-reported impact of female-Perpetrated childhood sexual abuse," Journal of Child Sexual Abuse, vol. 20, no. 1, pp. 58-76, 2011.

[20] J. Davidson, Child Sexual Abuse: Media Representations and Government Reactions, Routledge-Cavendish, Abingdon, UK, 2008.

[21] S. Hayes, Sex, Love and Abuse: Discourses of Domestic Violence and Sexual Assault, Palgrave Macmillan, Bassingstoke, UK, 2014.
[22] M. S. Denov, "The long-term effects of child sexual abuse by female perpetrators: a qualitative study of male and female victims," Journal of Interpersonal Violence, vol. 19, no. 10, pp. 1137-1156, 2004.

[23] N. J. Freeman and J. C. Sandler, "Female and male sex offenders: a comparison of recidivism patterns and risk factors," Journal of Interpersonal Violence, vol. 23, no. 10, pp. 1394-1413, 2008.

[24] S. Angelides, "Subjectivity under erasure: adolescent sexuality, gender, and teacher-student sex," Journal of Men's Studies, vol. 15 , no. 3, pp. 347-360, 2007.

[25] S. K. Wurtele, M. Kvaternick, and C. F. Franklin, "Sexual abuse prevention for preschoolers: a survey of parents' behaviors, attitudes, and beliefs," Journal of Child Sexual Abuse, vol. 1, no. 1, pp. 113-128, 1992.

[26] S. Morison and E. Greene, "Juror and expert knowledge of child sexual abuse," Child Abuse \& Neglect, vol. 16, no. 4, pp. 595-613, 1992.

[27] M. Schippers, "Recovering the feminine other: masculinity, femininity, and gender hegemony," Theory and Society, vol. 36, no. 1, pp. 85-102, 2007.

[28] M. J. Ball and S. L. Hayes, "Same-sex intimate partner violence: exploring the parameters," in Queering Paradigms, B. Scherer, Ed., pp. 161-177, Peter Lang AG, Bern, Switzerland, 2010.

[29] R. White and F. Haines, Crime and Criminology, Oxford University Press, 2008.

[30] C. West and D. H. Zimmerman, "Doing gender," Gender \& Society, vol. 1, no. 2, pp. 125-151, 1987.

[31] M. W. Wiederman, "The gendered nature of sexual scripts," The Family Journal, vol. 13, no. 4, pp. 496-502, 2005.

[32] E. Berrington and P. Honkatukia, "An evil monster and a poor thing: female violence in the media," Journal of Scandinavian Studies in Criminology and Crime Prevention, vol. 3, pp. 50-72, 2002.

[33] M. Morash, Understanding Gender, Crime and Justice, Sage, Thousand Oaks, Calif, USA, 2006.

[34] M. R. Burt and R. E. Estep, "Apprehension and fear: Learning a sense of sexual vulnerability," Sex Roles, vol. 7, no. 5, pp. 511-522, 1981.

[35] A. Linders and A. van Gundy-Yoder, "Gall, gallantry, and the gallows: capital punishment and the social construction of gender, 1840-1920," Gender \& Society, vol. 22, no. 3, pp. 324348, 2008.

[36] L. J. Graham, "Discourse analysis and the critical use of foucault," in Proceedings of the Australian Association for Research in Education Annual Conference, Sydney, Australia, NovemberDecember 2005.

[37] M. M. Dean, Critical and Effective Histories: Foucault's Methods and Historical Sociology, Routledge, London, UK, 1994.

[38] S. Taylor, "Researching educational policy and change in 'new times': using critical discourse analysis," Journal of Education Policy, vol. 19, no. 4, pp. 433-451, 2004.

[39] A. Nelson and P. Oliver, "Gender and the construction of consent in child-adult sexual contact: beyond gender neutrality and male monopoly," Gender and Society, vol. 12, no. 5, pp. 554$577,1998$. 

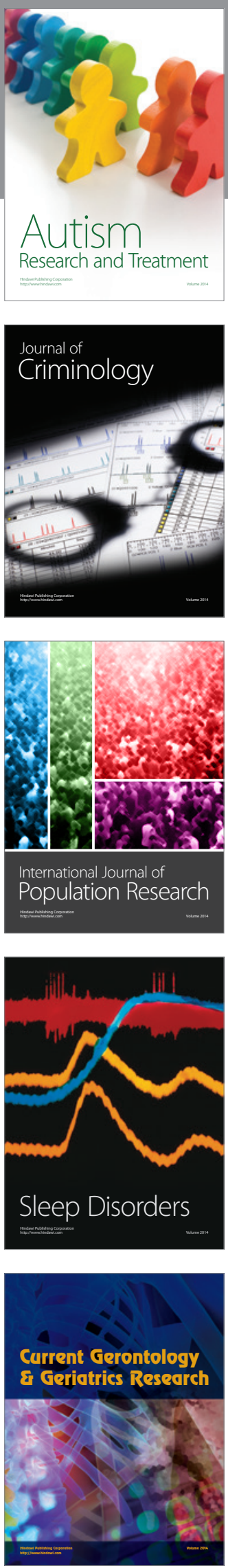
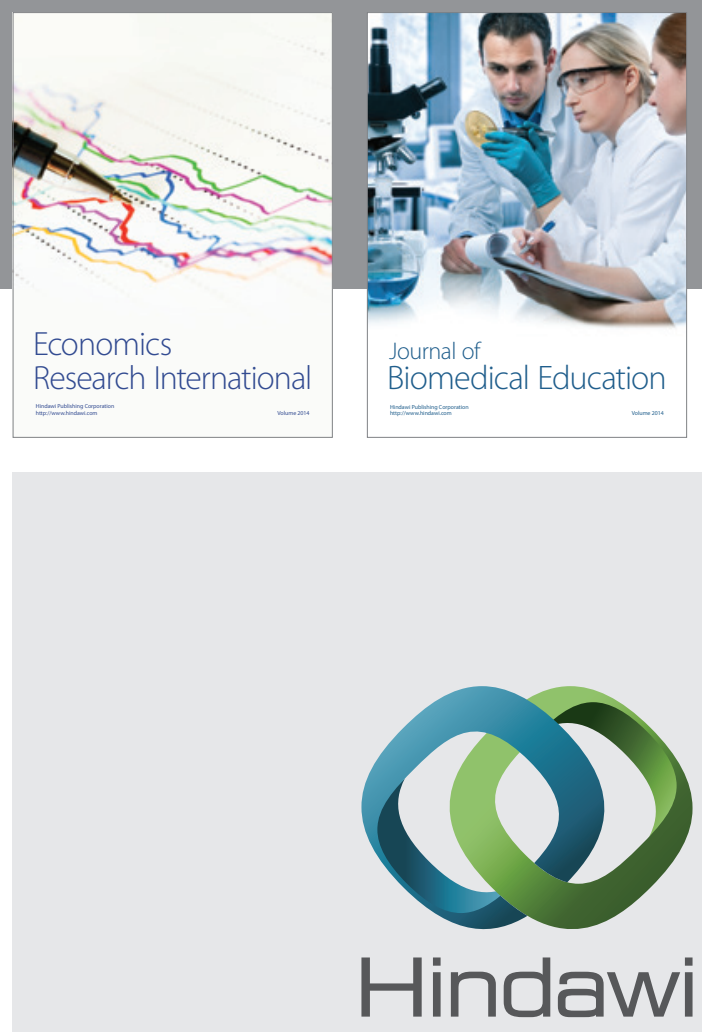

Submit your manuscripts at

http://www.hindawi.com
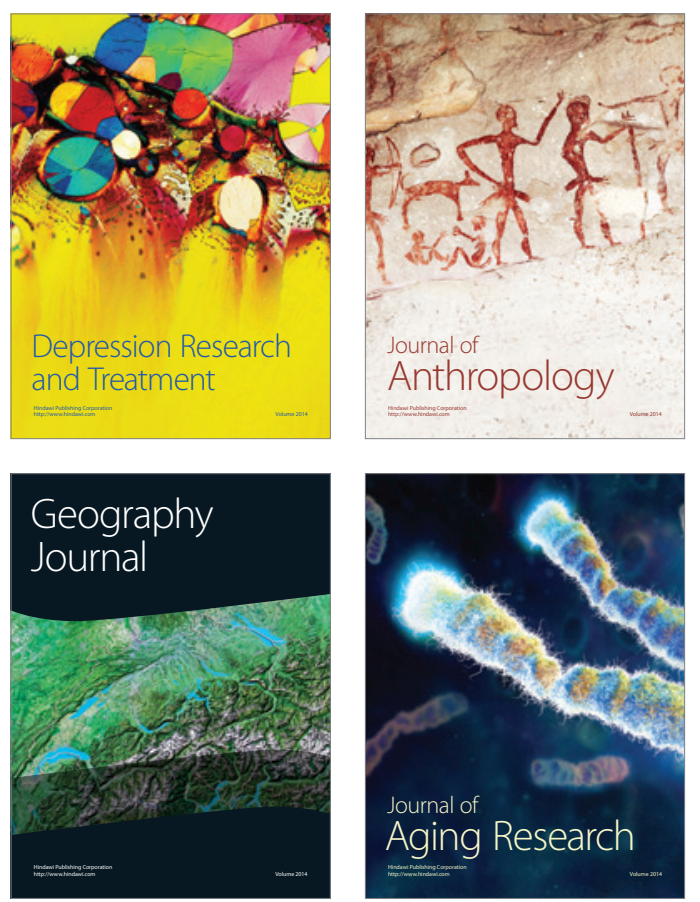
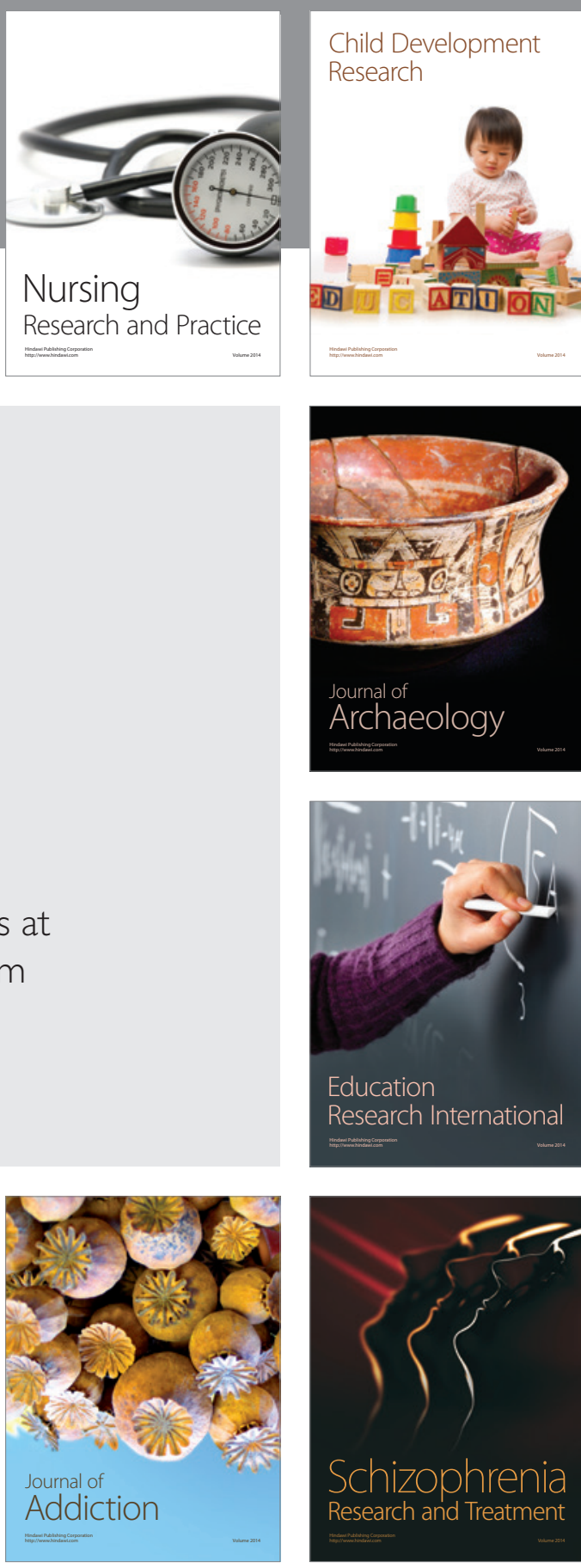

(D)
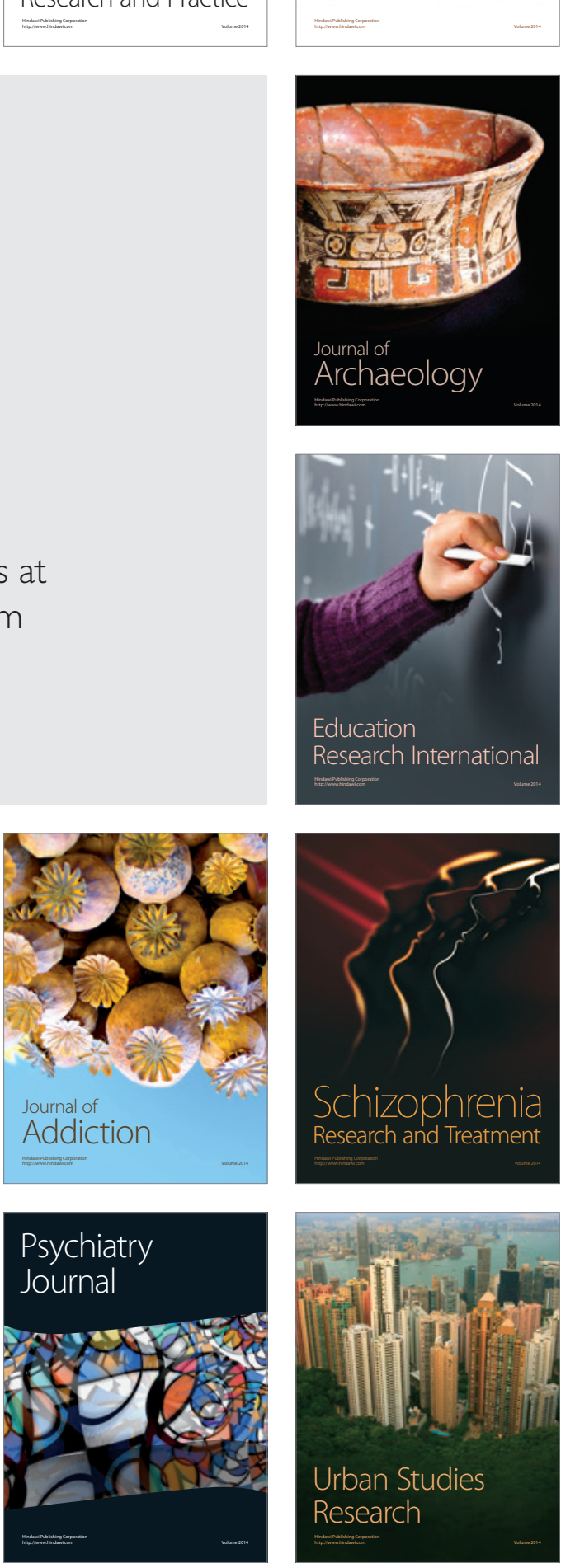